\title{
A new species of Foza Reed \& Cumberlidge, 2006, from northern Madagascar (Decapoda, Brachyura, Potamoidea, Potamonautidae), with a redescription of F. goudoti (H. Milne Edwards, I853) comb. n., and comments on Skelosophusa prolixa Ng \& Takeda, 1994
}

\author{
Neil Cumberlidge ${ }^{\dagger}$, Kirstin S. Meyer ${ }^{\ddagger}$ \\ Department of Biology, Northern Michigan University, Marquette, MI 49855, USA \\ † urn:lsid:zoobank.org:author:05F6365E-D168-4AE3-B511-80FA7E31ACC1 \\ †urn:lsid:zoobank.org:author:AFE96B64-F661-44C4-BE21-11BCFAFF8192 \\ Corresponding authors: Neil Cumberlidge (ncumberl@nmu.edu), Kirstin Meyer (kimeyer@nmu.edu) \\ Academic editor: Niel Bruce | Received 17 February 2009 | Accepted 31 July 2009 | Published 26 August 2009 \\ urn:lsid:zoobank.org:pub:9A407E72-AFDF-4997-AD04-D9FDAA54C3F3 \\ Citation: Cumberlidge N, Meyer KS (2009) A new species of Foza Reed \& Cumberlidge, 2006, from northern Madaga- \\ scar (Decapoda, Brachyura, Potamoidea, Potamonautidae), with a redescription of F goudoti (H. Milne Edwards, 1853) \\ comb. n., and comments on Skelosophusa prolixa Ng \& Takeda, 1994. In: Bruce N (Ed) Advances in the taxonomy and \\ biogeography of Crustacea in the Southern Hemisphere. ZooKeys 18: 77-89. doi: 10.3897/zookeys.18.102
}

\begin{abstract}
Foza ambohitra sp. n. is described from Ambohitra, Antsiranana Province, northern Madagascar at $421 \mathrm{~m}$ elevation. This species is distinguished by characters of the carapace, the male anterior thoracic sternum, and the form of the male major cheliped and first gonopod. Thelphusa goudoti H. Milne Edwards, 1853, is transferred to Foza Reed \& Cumberlidge, 2006, and redescribed, and a key to the three species of this genus is provided. Comments on the rare cave crab Skelosophusa prolixa $\mathrm{Ng} \&$ Takeda, 1994, from Antsiranana Province are also included based on newly obtained material.
\end{abstract}

\section{Keywords}

Potamoidea, Potamonautidae, Foza, new species, Madagascar, identification key

Copyright N Cumberlidge, KS Meyer. This is an open access article distributed under the terms of the Creative Commons Attribution License, which permits unrestricted use, distribution, and reproduction in any medium, provided the original author and source are credited. 


\section{Introduction}

The present work reports on the discovery of a new species of freshwater crab, Foza ambohitra, from Antsiranana Province in northern Madagascar, from material obtained over a number of years by different collectors. In addition, Hydrothelphusa goudoti $(\mathrm{H}$. Milne Edwards, 1853) is redescribed and reassigned here to Foza Reed \& Cumberlidge, 2006, and a key to the three species of this genus is provided. We also describe new characters of the rare cave crab Skelosophusa prolixa $\mathrm{Ng} \&$ Takeda, 1994, and provide habitus photographs of a large adult male specimen.

\section{Material}

The material is housed in the collections listed below:

FMNH Field Museum of Natural History, Chicago, Illinois, USA

MNHN Muséum national d'Histoire naturelle, Paris, France

NMU Department of Biology, Northern Michigan University, Marquette, Michigan, USA

NHM The Natural History Museum, London, UK

ZRC Zoological Research Collection, Raffles Museum of Biodiversity Research, National University of Singapore

\section{Methods}

All measurements were made with digital calipers, and are given in millimetres. Carapace width $(\mathrm{CW})$ is the distance across the carapace at the widest point; the carapace length $(\mathrm{CL})$ is measured along the median line, from the anterior to the posterior margin; the carapace height $(\mathrm{CH})$ is the maximum height of the cephalothorax from the highest point of the gastric region to the suture between thoracic sternites s2 and s3; the front width $(\mathrm{FW})$ is measured along the anterior frontal margin between the base of the orbits. The following abbreviations are used: a1-a6, abdominal somites 1-6; a7, telson of abdomen; asl, above sea level; e, thoracic episternite; s4/e4, s5/e5, s6/e6, s7/ e7, episternal sulci between respective thoracic sternites and episternites thoracic sternite; GO1, first gonopod; GO2, second gonopod; p1-p5, pereiopods 1-5; s4/s5, s4/ $s 5, s 5 / s 6, s 6 / s 7, s 7 / s 8$, sternal sulci between respectively numbered thoracic sternites. The terminology is adapted from Cumberlidge (1999). Line drawings were prepared using a Leica MZ 16 stereobinocular microscope. Photographs were taken with a digital camera in combination with an eyepiece adapter. Post processing was done in Adobe Photoshop 7.0. 


\section{Description}

\section{Foza ambohitra sp. n.}

urn:Isid:zoobank.org:act:1007E7DF-D87E-41A9-AB9D-B3628DB72C7D

(Figs 1-3, Table 1)

Type material. Holotype: adult male (CW 39.5, CL 32.4, CH 16.3, FW 8.7) northern Madagascar: Antsiranana Province, Diana Region, forest close to Ambohitra

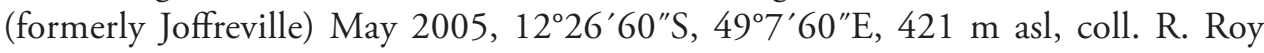
(MNHN B 30154). Paratypes: adult female (CW 37.8, CL 29.6, CH 15.5, FW 8.0), subadult female (CW 30.0, CL 23.6, CH 12.7, FW 6.6), northern Madagascar: Antsiranana Province, Réserve Spéciale d'Analamerana, Foret d'Ankavanana, $15.8 \mathrm{~km}$ southeast Anivorano-Nord, from partially disturbed mixed dry deciduous and humid forest, collected in early morning, 23 January 2004, $14^{\circ} 52^{\prime} 00^{\prime \prime} \mathrm{S}$, $50^{\circ} 15^{\prime} 20^{\prime \prime} \mathrm{E}, 200 \mathrm{~m}$ asl, coll. S. M. Goodman (FMNH 11045); adult male (CW 38.4, CL 28.8, CH 15.0, FW 8.3), adult female (CW 35.0, CL 28.0, CH 14.3, FW 8.1), Antsiranana Province, Réserve Spéciale d'Analamerana, Foret d'Ankavanana, $15.8 \mathrm{~km}$ southeast Anivorano-Nord, from partially disturbed mixed dry deciduous and humid forest, collected during night at edge of small stream at forest edge, 23 January 2004, 14 $4^{\circ} 52^{\prime} 00^{\prime \prime}$ S, 50 $15^{\circ} 20^{\prime \prime} \mathrm{E}, 200 \mathrm{~m}$ asl, coll. S. M. Goodman (FMNH 11046); adult male (CW 37.1, CL 29.2, CH 16.8, FW 8.1), Antsiranana Province, Réserve Spéciale d'Analamerana, Foret d'Ankavanana, 15.8 km southeast AnivoranoNord, from partially disturbed mixed dry deciduous and humid forest, collected in late afternoon, 25 January $2004,14^{\circ} 52^{\prime} 00^{\prime \prime} \mathrm{S}, 50^{\circ} 15^{\prime} 20^{\prime \prime} \mathrm{E}, 200 \mathrm{~m}$ asl, coll. S. M. Goodman (FMNH 11050); adult female (CW 38.0, CL 28.7, CH 15.7, FW 8.5), adult male (CW 33.2, CL 26.2, CH 14.5, FW 7.5), Antsiranana Province, Réserve Spéciale d'Analamerana, Foret d'Ankavanana, $15.8 \mathrm{~km}$ southeast Anivorano-Nord, from partially disturbed mixed dry deciduous and humid forest, collected in the late afternoon, 25 January $2004,14^{\circ} 52^{\prime} 00^{\prime \prime} \mathrm{S}, 50^{\circ} 15^{\prime} 20^{\prime \prime} \mathrm{E}, 200 \mathrm{~m}$ asl, coll. S. M. Goodman (FMNH 11051); adult female (CW 39.1, CL 30.7, CH 17.1, FW 8.7) Antsiranana Province, Réserve Spéciale d'Analamerana, Foret d'Ankavanana, 15.8 $\mathrm{km}$ southeast Anivorano-Nord, from partially disturbed mixed dry deciduous and humid forest, collected at forest edge during night, 25 January 2004, $14^{\circ} 52^{\prime} 00^{\prime \prime} \mathrm{S}$, $50^{\circ} 15^{\prime} 20^{\prime \prime} \mathrm{E}, 200 \mathrm{~m}$ asl, coll. S. M. Goodman (FMNH 11052); adult female (CW 41.4, CL 31.9, CH 17.4, FW 8.7) Antsiranana Province, Réserve Spéciale d'Analamerana, Foret d'Ankavanana, $15.8 \mathrm{~km}$ southeast Anivorano-Nord, from partially disturbed mixed dry deciduous and humid forest, found on ground during day, 26 January 2004, $14^{\circ} 52^{\prime} 00^{\prime \prime}$ S, 50 $0^{\circ} 15^{\prime} 20^{\prime \prime} \mathrm{E}, 200 \mathrm{~m}$ asl, coll. S. M. Goodman (FMNH 11054); adult female (CW 43.1, CL 34.2, CH 18.3, FW 9.9), Antsiranana Province, Réserve Spéciale d'Analamerana, Foret d'Ankavanana, $15.8 \mathrm{~km}$ southeast Anivorano-Nord, from partially disturbed mixed dry deciduous and humid forest, collected in late afternoon, 28 January 2004, $14^{\circ} 52^{\prime} 00^{\prime \prime} \mathrm{S}, 50^{\circ} 15^{\prime} 20^{\prime \prime} \mathrm{E}, 200 \mathrm{~m}$ asl, coll. S. M. Goodman (FMNH 11056); juvenile male (CW 22.8, CL 17.6, CH 9.4, 
A

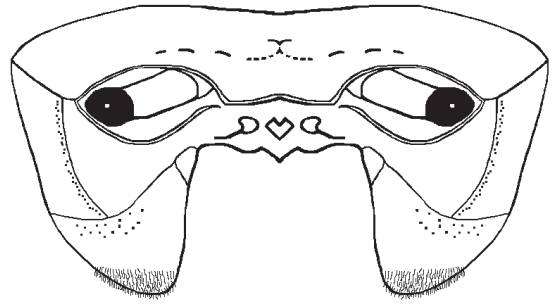

B

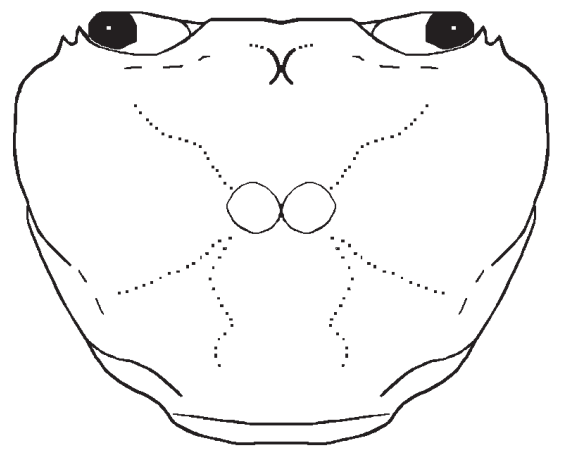

C
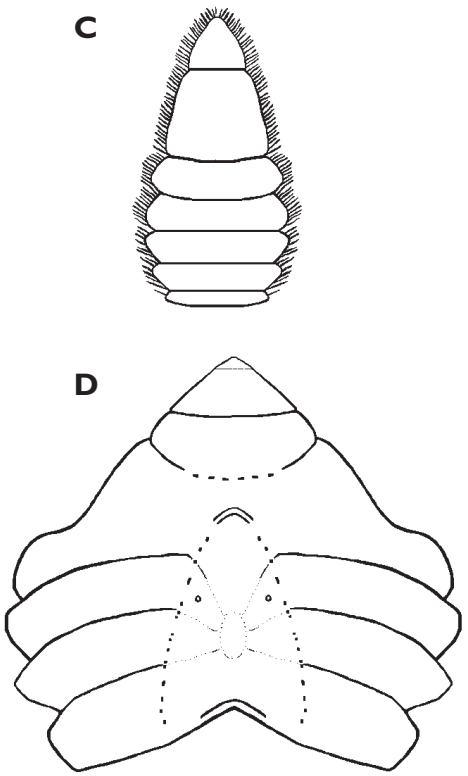
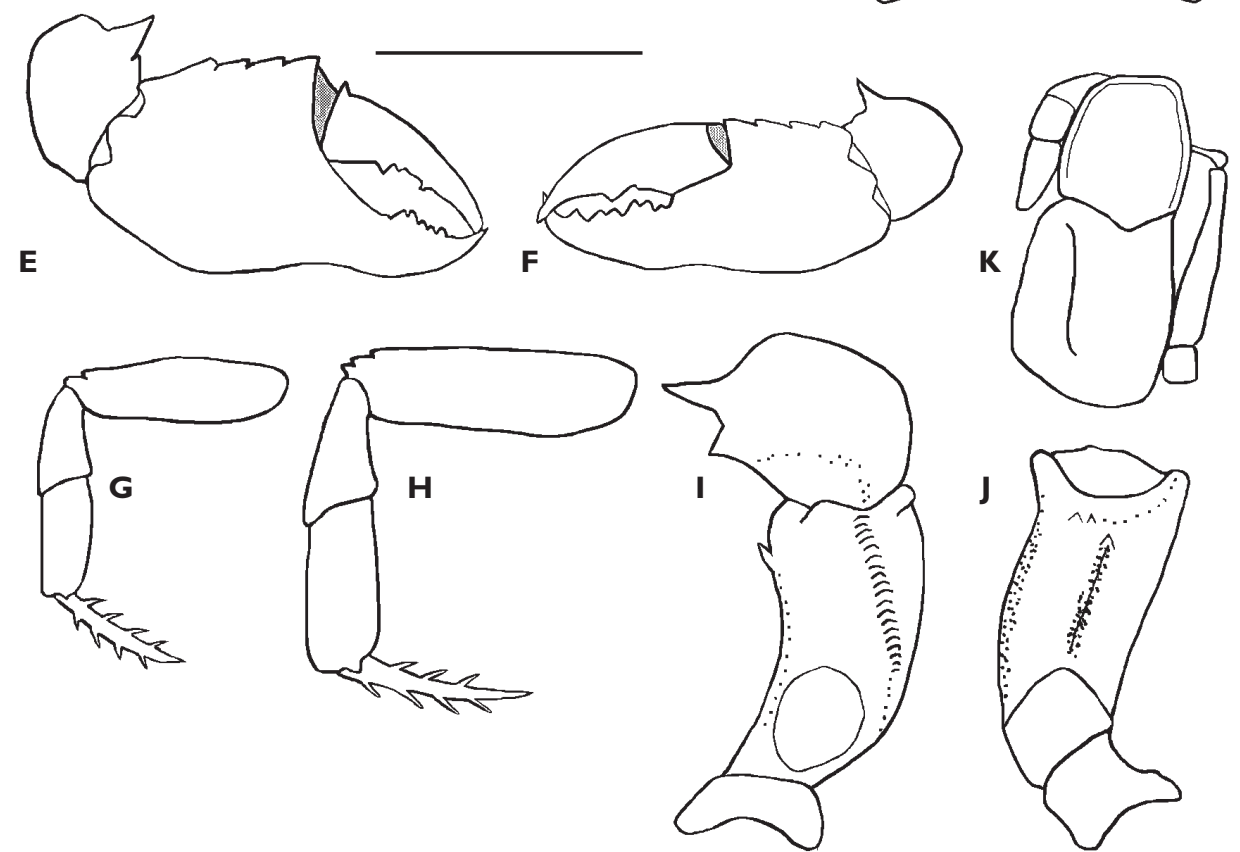

Figure I. Foza ambohitra sp. n. A carapace, frontal view B carapace, dorsal view $\mathbf{C}$ male abdomen $\mathbf{D}$ male sternum $\mathbf{E}$ major (right) cheliped $\mathbf{F}$ minor (left) cheliped $\mathbf{G}$ pereiopod $3 \mathbf{H}$ pereiopod $5 \mathbf{I}$ carpus and merus of major cheliped, dorsal view $\mathbf{J}$ merus of major cheliped, ventral view $\mathbf{K}$ third maxilliped. Scale bar $=20 \mathrm{~mm}, \mathbf{A}-\mathbf{J} ; 7.5 \mathrm{~mm}, \mathbf{K}$. 
FW 4.7) Antsiranana Province, Réserve Spéciale d'Analamerana, $8.6 \mathrm{~km}$ southeast Menagisy, Foret d'Analabe, along Bobakindro River, partially disturbed dry deciduous forest, collected early morning, 17 January $2004,12^{\circ} 42^{\prime} 00^{\prime \prime} \mathrm{S}, 49^{\circ} 28^{\prime} 00^{\prime \prime} \mathrm{E}, 40$ $\mathrm{m}$ asl, coll. S. M. Goodman (FMNH 11060); adult male (CW 43.0, CL 31.6, CH 17.7, FW 11.6), Toamasina Province, Montagne d'Akirindro, 7.6 km, 17-21 March 2003, 1517'00"S, 49³2'34"E, NNE Ambinantelo, 600 m asl, coll. P. Naskrecki (NMU PN 17-21.3.2003).

Diagnosis. Anterolateral margin lined by small granules. Suborbital, subhepatic, pterygostomial regions smooth with small field of granules at junction of longitudinal, vertical sutures. Outer face of merus of cheliped (pereiopod 1) smooth, granules present on upper margin only. Sternal sulcus s3/s4 complete, U-shaped, not meeting sterno-abdominal cavity. Terminal article of GO1 short, slim, tapered, with distinct raised rounded shoulder on external margin, slightly lower than junction with terminal article.

Description. Based on holotype, adult male. Carapace outline transversely oval, very high $(\mathrm{CH} / \mathrm{FW} 1.90)$; front narrow $(\mathrm{FW} / \mathrm{CW} 0.22)$, deflexed; epibranchial tooth small, pointed, advanced in position, almost touching exorbital tooth; anterolateral margin evenly curved outward, lined by small granules, continuous with posterolateral margin, latter margin with faint or absent striae; postfrontal crest faint to absent, epigastric crests faint, positioned forward on front almost touching frontal margin, postorbital crests faint; deep mid-groove between epigastric crests forked posteriorly; cardiac, urogastric grooves faint, semicircular grooves deep; cervical grooves faint, long, not meeting postorbital crest. Suborbital region of carapace smooth, subhepatic region smooth, pterygostomial region smooth except for setae on lower margin, small field of granules at junction between longitudinal, vertical sutures; vertical sulcus on carapace sidewall curved, granular, running downward from base of epibranchial tooth to epimeral sulcus.

Epistomial tooth triangular, deflexed, edges smooth. Mandibular palp bilobed. Exopod of third maxilliped reaching to lower half of merus, exopod with short flagellum, ischium with deep vertical groove, curving distally toward medial margin. Sternal sulcus $s 1 / \mathrm{s} 2$ short, very faint; sternal sulcus $s 2 / s 3$ completely crossing sternum; sternal sulcus $s 3 / s 4$ with broad U-shaped groove, deep at edges, faint in middle; anterior sterno-abdominal cavity lacking setae. Sternal sulcus s4/s5 meeting abdomen at abdominal sulcus at a7/a6; sternal sulcus s6/s7 meeting a 6 one half of segment length from a6/ a5. Episternal sulci s4/e4, s5/e5, s6/e6, s7/e7 absent, smooth.

Dactylus of both chelipeds relatively slender, approximately one-third height of palm, edges smooth except for 2 distinct teeth, one positioned basally, one half way along; upper margin of dactylus smooth; lower margin of propodus slightly indented. Fixed finger of propodus of major (right) cheliped slender with 3 large molars in proximal region (first 2 fused basally, third single) followed by series of small teeth. First carpal tooth on inner margin of carpus of cheliped large, pointed; second carpal tooth smaller, pointed, followed by a large granule. Medial, lateral margins of inferior face of merus of cheliped distinctly toothed, inferior face with 

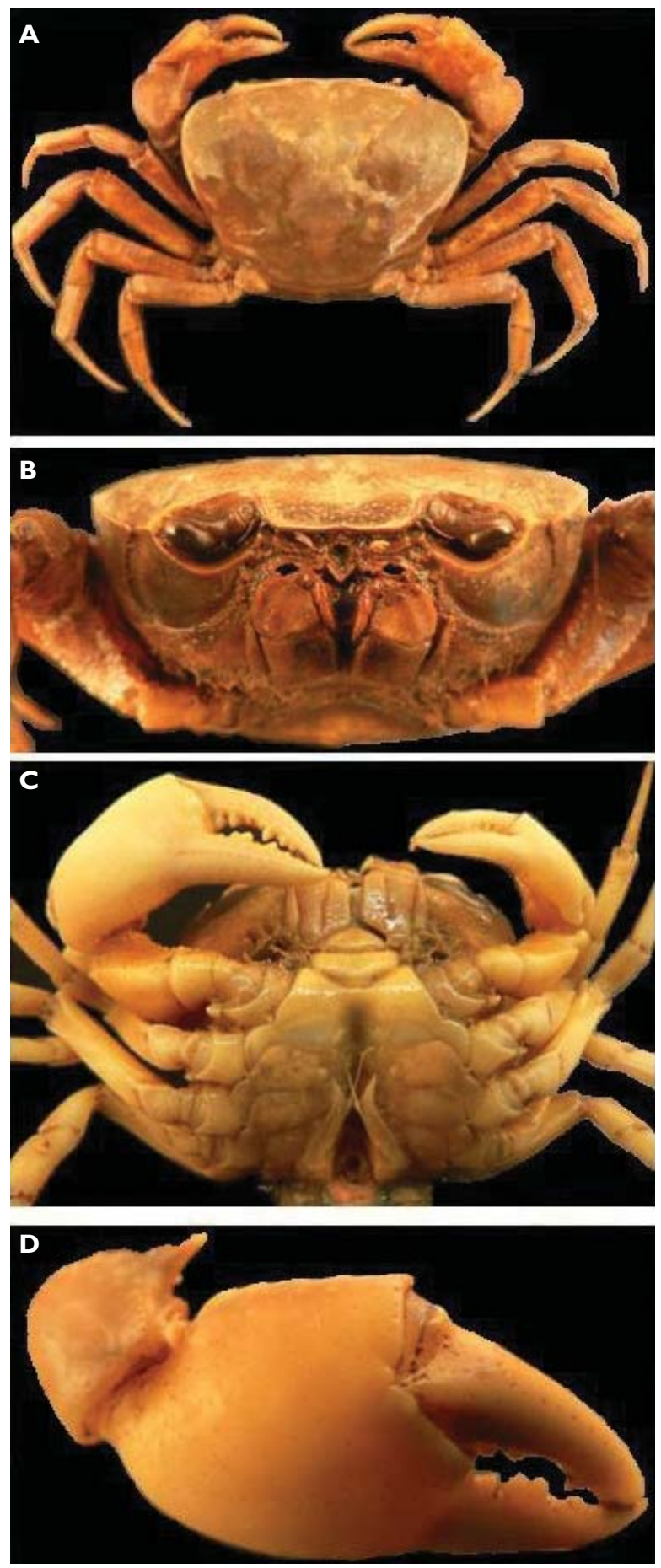

Figure 2. Foza ambohitra sp. n. A dorsal view $\mathbf{B}$ frontal view $\mathbf{C}$ sternal view $\mathbf{D}$ major (right) cheliped. A, B adult female (FMNH 11056), CW $43.1 \mathrm{~mm}$ C, D holotype, adult male, CW $39.5 \mathrm{~mm}$. 
pointed, granulated distal meral tooth; superior margin of merus of cheliped roughened by granules and short striae; outer face of merus smooth; granules on medial margin of merus, ischium of cheliped smooth, inferior margin of ischium rounded, smooth. Walking legs (p2-p5) elongated (ratio of merus length of p5 to CW 0.3), slender, inner margins of $\mathrm{p} 2$ to $\mathrm{p} 5$ propodi smooth. Male abdomen triangular, tapered distally, widest at a3, narrowest at a7 (telson); telson outline forming straightsided triangle with broad base, rounded apex.

Terminal article of GO1 short (ratio of length of terminal article to subterminal segment 0.25 ), slim, tapered, directed slightly outwards, straight, smooth, apical
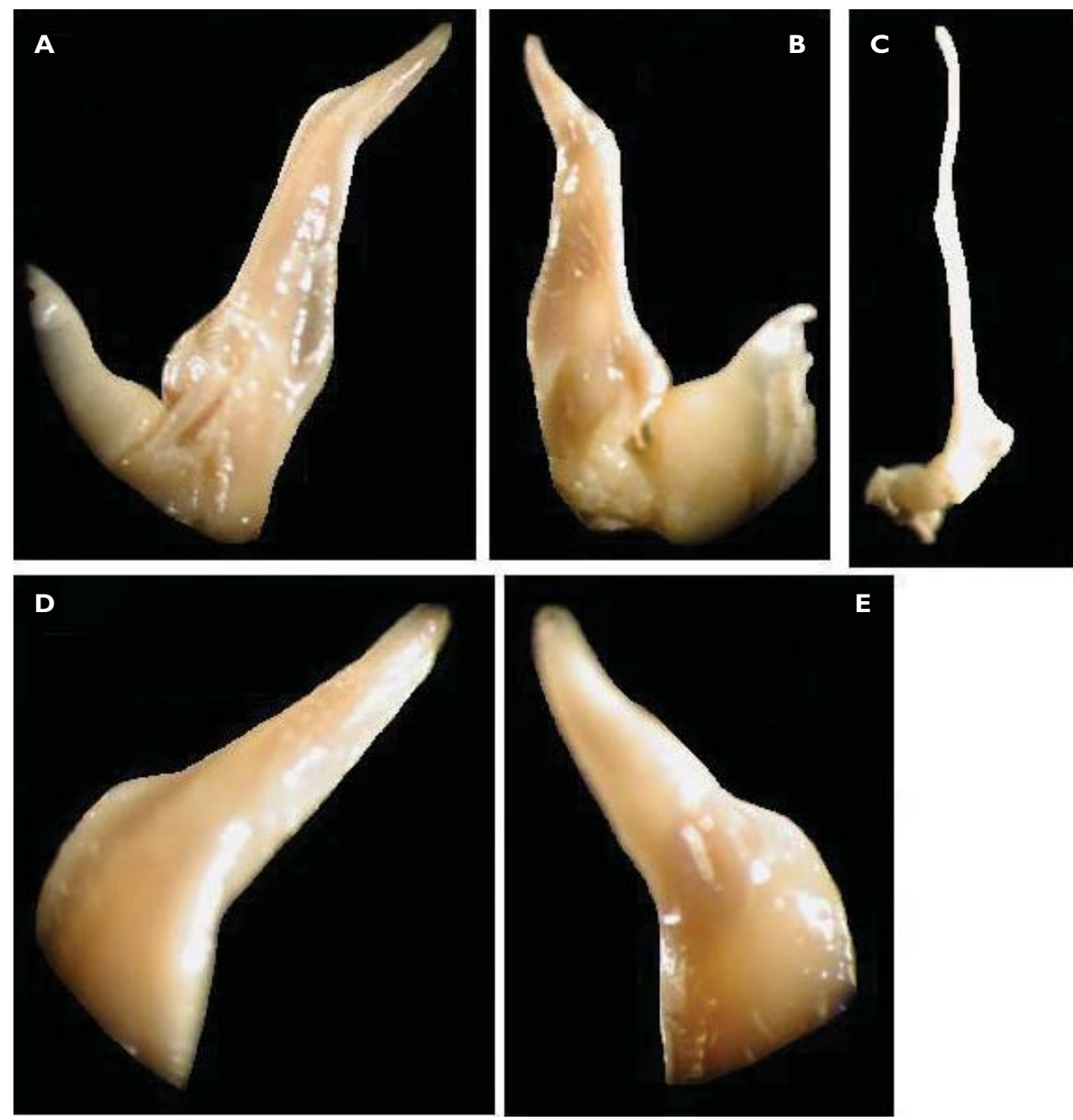

Figure 3. Foza ambohitra sp. n. A left GO1, ventral view B left GO1, dorsal view C left GO2, ventral view $\mathbf{D}$ terminal article of left GO1, close-up, ventral view $\mathbf{E}$ terminal article of left GO1, close-up, dorsal view. Holotype, adult male, length of the terminal article measured along the mid-line of the dorsal face from tip to dorsal membrane $=8.2 \mathrm{~mm}$. 
opening narrow; subterminal segment with junction between terminal article, subterminal segment not clearly visible on ventral side. Terminal article, subterminal segment separated on dorsal side by broad, trapezoid dorsal membrane; superior margin of dorsal membrane formed by diagonal basal margin of terminal article, inferior margin of membrane formed by diagonal J-shaped distal edge of subterminal segment; lateral margin of dorsal membrane broad, medial margin of membrane narrow, forming medial junction between subterminal segment, terminal article. Subterminal segments of GO1, GO2 subequal, but terminal article of GO2 much longer than terminal article of GO1. Terminal article of GO2 flagellum-like, about $2 / 3$ length of subterminal segment, reaching anterior margin of sterno-abdominal cavity; tip of flagellum curving inward distally; distal parts of flagella of left, right GO2s crossing medially.

Comparisons. Foza ambohitra, sp. n., is assigned to the genus Foza on the basis of characters that it shares with F. raimundi Reed \& Cumberlidge, 2006, the typespecies of the genus (Reed and Cumberlidge, 2006). The two species share a weak postfrontal crest, a narrow frontal margin of the carapace (FW/CW 0.22 F. ambohitra, 0.25 F. raimundi) and a GO2 terminal article that curves inward distally; and the epibranchial tooth of both species is in a forward position, almost touching the exorbital tooth. Foza ambohitra can be distinguished from F. raimundi as follows: the terminal article of GO1 of $F$. ambohitra is cone-shaped and tapered (Fig. 2A), while that of F raimundi is tube-shaped (Reed and Cumberlidge, 2006: Fig. 2B-D); both the superior part of the pterygostomial region and the sterno-abdominal cavity of F. ambohitra lack setae (Fig. 1D, 2C), whereas setae are present in these regions in $F$. raimundi; the anterolateral margin of $F$ ambohitra is granular and the posterolateral margin is smooth (Fig. 1A), whereas the anterolateral margin of F. raimundi is smooth and the posterolateral margin is carinated (Reed and Cumberlidge, 2006: Fig. 1B); and the major cheliped of $F$. ambohitra has three large molars (Fig. 1E) whereas that of $F$ raimundi has one large fused molar (Reed and Cumberlidge, 2006: Fig. 1E). The three species of Foza are compared in Table 1. The differences between Foz $d$ and the other Malagasy freshwater crab genera are discussed by Reed and Cumberlidge (2006).

Etymology. Ambohitra is the modern name of Joffreville, a French colonial town in northern Madagascar, near where the specimens described here were collected. Ambohitra is a noun in apposition.

Distribution. Foza ambohitra is found in the Analamerana Mountains $\left(12^{\circ} 44^{\prime} 00^{\prime \prime} \mathrm{S}\right.$, $\left.49^{\circ} 36^{\prime} 00^{\prime \prime} \mathrm{E}\right)$, as well as the Ankavanana River $\left(14^{\circ} 52^{\prime} 00^{\prime \prime} \mathrm{S}, 50^{\circ} 15^{\prime} 20^{\prime \prime} \mathrm{E}\right)$ and the Bobakindro River $\left(12^{\circ} 42^{\prime} 00^{\prime \prime} \mathrm{S}, 49^{\circ} 28^{\prime} 00^{\prime \prime} \mathrm{E}\right)$ in Antsiranana Province in northeastern Madagascar.

Habitat. Partially disturbed mixed dry deciduous and humid forest in northern Madagascar. 


\section{Redescription}

Foza goudoti (H. Milne Edwards, 1853), comb. n.

Thelphusa goudoti $\mathrm{H}$. Milne Edwards, 1853: 212. A. Milne-Edwards 1869: 172; 1887: 135.

Telphusa goudoti.- De Man 1892: 235.

Potamon goudoti.- De Man 1898: 434.

Potamon (Potamon) goudoti.- Rathbun, 1904: 305, 306. Balss 1929: 355.

Potamon (Geothelphusa) methueni Calman, 1913: 920.

Bottia goudoti.- Pretzmann 1961: 164.

Gecarcinautes goudoti.- Bott 1965: 338, 339. Cumberlidge 1997: 585; 1998: 209.

Hydrothelphusa goudoti.- Cumberlidge and Sternberg 2002: 56-59. Ng et al., 2008: 169.

Type locality. Madagascar. Thelphusa goudoti: Madagascar, road between Bombetok and Tananarive. Potamon (Geothelphusa) methueni: Imerimandrosa.

Type material. Adult male (CW 45.3, CL 34.4, CH 20.7, FW 10.7), adult female (CW 40.5, CL 32.1, CH 17.0, FW 10.0), 1987, purchased live in market in Antananarivo by N. Cumberlidge (NMU NC 1987); adult male (CW 38.0, CL 28.1, CH 15.1, FW 10.2), adult male (CW 34.4, CL 27.5, CH 14.5, FW 8.4), adult female (CW 38.2, CL 33.1, CH 17.0, FW 9.5), adult female (CW 32.0, CL 25.1, CH 13.6, FW 8.2), from a lake near Antananarivo, coll. H. Morioka (ZRC 2000.2303).

Diagnosis. Frontal margin of carapace relatively narrow (FW/CW 0.25), sharply deflexed. Epibranchial tooth small, positioned forward close to exorbital tooth. Epigastric, postorbital crests fused forming long horizontal postfrontal crest. Anterolateral margin posterior to epibranchial tooth raised, granular; anterolateral region smooth with striae on posterolateral margin. Pterygostomial region of carapace sidewall lacking setae. Subhepatic region smooth, granules in suborbital and pterygostomial regions. Sternal sulcus s3/s 4 complete, $v$-shaped. Terminal article of GO1 with medial flap near junction. Terminal article of GO2 long, not curving inward distally.

Comparisons. Cumberlidge and Sternberg (2002) assigned T. goudoti to Hydrothelphusa on the basis of its bilobed mandibular palp, but commented on the differences in a number of other characters of the carapace between this species and the others included in that genus. For example, the exorbital and epibranchial teeth of F. goudoti are both low and blunt and positioned close together, and the carapace is very wide $(\mathrm{CW} / \mathrm{FW} 3.9)$ and highly arched $(\mathrm{CH} / \mathrm{FW} 1.6)$. In the other species of Hydrothelphsua these teeth are large and well spaced, and the carapace is not noticeably widened or inflated (Cumberlidge and Sternberg, 2002). This taxon is transferred here to the genus Foza because it shares a number of important taxonomic characters with both $F$. raimundi and $F$. ambohitra (Table 1). 
Table I. Comparison of the morphological characters of the species of genus Foza.

\begin{tabular}{|c|c|c|c|}
\hline Character & F. raimundi ${ }^{1}$ & F. goudoti ${ }^{2}$ & F. ambohitra ${ }^{3}$ \\
\hline GO1 terminal segment & $\begin{array}{l}\text { tube-shaped, not } \\
\text { tapering }\end{array}$ & $\begin{array}{l}\text { cone-shaped, taper- } \\
\text { ing }\end{array}$ & $\begin{array}{l}\text { cone-shaped, taper- } \\
\text { ing }\end{array}$ \\
\hline GO2 terminal segment & $\begin{array}{l}\text { curving inward dis- } \\
\text { tally }\end{array}$ & $\begin{array}{l}\text { straight, no distal } \\
\text { curve }\end{array}$ & $\begin{array}{l}\text { curving inward dis- } \\
\text { tally }\end{array}$ \\
\hline Sterno-abdominal cavity & dense setae & no setae & no setae \\
\hline Sternal sulcus s3/s4 & complete, u-shaped & complete, v-shaped & complete, u-shaped \\
\hline Postfrontal crest & faint, incomplete & distinct, complete & faint, incomplete \\
\hline $\begin{array}{l}\text { Anterolateral surface of } \\
\text { carapace }\end{array}$ & smooth & smooth & granular \\
\hline Anterolateral margin & smooth & raised, granular & smooth \\
\hline $\begin{array}{l}\text { Posterolateral surface of } \\
\text { carapace }\end{array}$ & with carinae & with carinae & smooth \\
\hline Cervical grooves & short & long, distinct & long, faint \\
\hline Suborbital region & small granules & faint granules & smooth \\
\hline Subhepatic region & conspicuous carinae & smooth & smooth \\
\hline Pterygostomial region & $\begin{array}{l}\text { dense setae on en- } \\
\text { tire region, lacking } \\
\text { granules }\end{array}$ & $\begin{array}{l}\text { setae absent, gran- } \\
\text { ules present }\end{array}$ & $\begin{array}{l}\text { setae near inferior } \\
\text { margin only, small } \\
\text { field of granules at } \\
\text { junction of vertical } \\
\text { and epimeral sutures }\end{array}$ \\
\hline Major cheliped & one fused molar & more than one molar & three distinct molars \\
\hline
\end{tabular}

${ }^{1}$ Reed and Cumberlidge, 2006; ${ }^{2}$ Cumberlidge and Sternberg, $2002 ;{ }^{3}$ present work.

\section{Key to the species of Foza}

1 Terminal article of GO1 tube-shaped; dense setae on sterno-abdominal cavity and pterygostomial region; conspicuous striae present on subhepatic region; cervical grooves short; major cheliped with single fused molar.....

F. raimundi Reed \& Cumberlidge, 2006

- $\quad$ Terminal article of GO1 cone-shaped, tapering to a pointed tip; setae lacking on sterno-abdominal cavity and superior part of pterygostomial region; subhepatic region smooth, smooth; cervical grooves long; major cheliped with more than one fused molar ................................................................... 2

2 Terminal article of GO2 long, straight; anterolateral region of carapace surface smooth; striae present on posterolateral region; postfrontal crest distinct, complete; suborbital, pterygostomial, subhepatic regions smooth, lacking granules at intersection of longitudinal, vertical sutures

F. goudoti (H. Milne Edwards, 1853)

- $\quad$ Terminal article of GO2 long, strongly curved inward at tip; anterolateral region of carapace surface with fields of striae; posterolateral region smooth; 
postfrontal crest weak, incomplete; suborbital, pterygostomial, subhepatic regions with small field of granules at intersection of longitudinal, vertical sutures

F. ambohitra sp. n.

\section{Remarks on Skelosophusa prolixa Ng and Takeda, 1994}

(Fig. 4)

The first author discovered five specimens from northern Madagascar in the unidentified collection of the NHM (NHM 2009.119, NHM 2009.120 -121, NHM 2009.122, NHM 2009.123, NHM 2009.124) that proved to belong to Skelosophusa prolixa. All of these specimens were collected from Riviére Cave, Cañon Forestier, Ankarana, $60 \mathrm{~km}$ south of Diego Suarez, northern Madagascar, 8 August-27 September 1986, by N. W. Lear and S. U. Fowler. Although the locality is similar to that reported for the holotype, it may be possible that these specimens are topotypic, and were collected at the same time as the original type series. However, it is difficult to be certain of this because the date of collection and the names of the collectors were not supplied in the original description ( $\mathrm{Ng}$ and Takeda, 1994). Skelosophusa prolixa was previously known only from two specimens collected from this same locality. The holotype described by $\mathrm{Ng}$ and Takeda (1994) has a CW of $25.6 \mathrm{~mm}$ and CL of $18.8 \mathrm{~mm}$; these two measurements give a cw/cl ratio of 1.3 (compared to 1.4 for the present specimens). This species possesses a number of adaptations (e.g. normal length eyestalks but
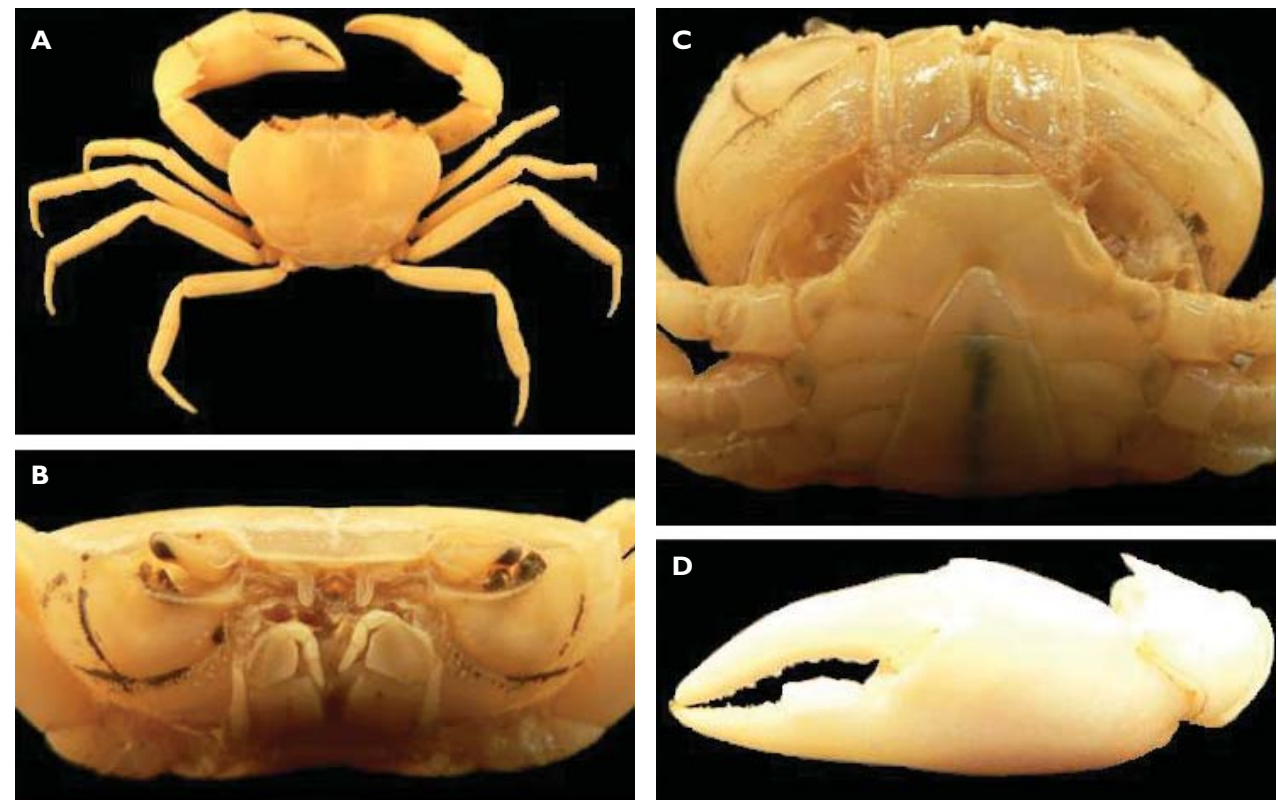

Figure 4. Skelosophusa prolixa. A dorsal view B frontal view C sternal view D major (left) cheliped. Adult male (NHM 2009.122), CW $29.3 \mathrm{~mm}$. 
with reduced corneas, lack of pigmentation of the carapace and legs, and extremely long ambulatory legs, p2-p5) typical of true cave-adapted species of freshwater crabs (Ng and Takeda, 1994). The adult male specimen among the new material photographed here (Fig. 4A-D) (CW $29.3 \mathrm{~mm}$ ) is larger than the holotype male (CW 25.6 $\mathrm{mm}$ ) and shows characters of the cheliped that have not previously been described. For example, the immovable finger of the major cheliped of $S$. prolixa has one large, fused molar tooth in adults, whereas that of the holotype male, a smaller specimen, has only small teeth (Ng and Takeda, 1994).

\section{Acknowledgements}

Prof. Danièle Guinot of the MNHN, Paris, France, is thanked for sending the holotype for identification that prompted this study. This work has been enhanced by the material collected from Madagascar over a number of years by Dr. Steven M. Goodman of the Field Museum, Chicago. Marty Prydzia, Joachim Gerber, and Dr. Janet Voight of the FMNH are also thanked for kindly loaning specimens used in this study and for hosting visits by the first author. We are grateful to Dr. Piotr Naskrecki, Museum of Comparative Zoology, Harvard University, Cambridge, Massachusetts, who donated several specimens of freshwater crabs from Madagascar, one of which proved to belong to F. ambohitra. Drs. Peter K. L. Ng and Darren C. J. Yeo of the National University of Singapore are thanked for loaning specimens of $F$ goudoti mentioned here. Finally, we thank Dr. Paul F. Clark and Miranda Lowe of The Natural History Museum, London, UK, who loaned specimens and hosted visits by the first author.

\section{References}

Balss H (1929) Über Ostafrikanischer Potamonidae (Decapoda). Mit Anhang: Potamoiden von Madagaskar. Zoologische Jahrbücher, Abteilung für Systematik 58: 339-358.

Bott R (1965) Die Süßwasserkrabben von Madagaskar. Bulletin du Muséum national d'Histoire naturelle 37 (2): 335-350.

Calman WT (1913) On Freshwater Decapod Crustacea (Families Potamonidae, Palaemonidae) collected in Madagascar by the Hon. Paul A. Methuen. Proceedings of the Zoological Society of London: 914-932.

Cumberlidge N (1997) The African and Madagascan freshwater crabs in the Museum of Natural History, Vienna (Crustacea: Decapoda: Brachyura: Potamoidea). Annalen des Naturhistorischen Museums in Wien 99B: 571-589.

Cumberlidge N (1998) The African and Madagascan freshwater crabs in the Zoologische Staatssammlung, Munich (Crustacea: Decapoda: Brachyura: Potamoidea). Spixiana 21 (3): 193-214.

Cumberlidge N (1999) The Freshwater Crabs of West Africa, Family Potamonautidae. Faune et Flore tropicales 35, IRD, Paris, 382 pp. 
Cumberlidge N, Sternberg R (2002) The freshwater crabs of Madagascar (Crustacea, Decapoda, Potamoidea). Zoosystema 24 (1): 41-79.

De Man JG (1892) Decapoden des Indischen Archipels, in Weber M (ed.) ZoologischeErgebnisse einer Reise in Niederländisch Ost-Indien 2: 265-527.

De Man JG (1898) Description d'une espèce nouvelle du Genre Potamon Sav. provenant du pays des Somalis. Annali del Museo Civico di Storia Naturale di Genova (2) 19 (29): 262-270.

Milne Edwards H (1853) Observations sur les affinités zoologiques et la classification naturelle des Crustacés. Annales des Sciences naturelles, Zoologie, Série 3, 20: 163-182.

Milne-Edwards A (1869) Révision du genre Thelphusa et description de quelques espèces nouvelles faisant partie de la collection du Muséum. Nouvelles Archives du Muséum d'Histoire naturelle 5: 161-191.

Ng PKL, Guinot D, Davie P (2008) Systema Brachyuorum: Part I. An annotated checklist of extant Brachyuran crabs of the world. Raffles Bulletin of Zoology Supplement 17: 1-286.

Ng PKL, Takeda M (1994) Skelosophusa (Crustacea, Decapoda, Brachyura), a new genus of potamonautid freshwater crab from Madagascar, with descriptions of two new species. Bulletin of the National Science Museum, Series A (Zoology) 20(4): 161-172.

Pretzmann G (1961) Die Reptantia der Oesterreichischen Madagaskar-Expedition 1958. Mémoires de l'Institut scientifique de Madagascar serie F, IV: 161-165.

Rathbun MJ (1904) Les crabes d'eau douce (Potamonidae). Nouvelles Archives du Muséum d'Histoire naturelle 6 (4): 255-312.

Reed SK, Cumberlidge N (2006) Foza raimundi, a new genus and species of potamonautid freshwater crab (Crustacea: Decapoda: Potamoidea) from northern Madagascar. Proceedings of the Biological Society of Washington 119(1): 58-66. 
